\title{
OPTION VALUE CALCULATION AFFECTED COMPONENTS
}

\author{
Ance Martinova $^{1}$
}

University of Latvia (Latvia)

\begin{abstract}
As the subprime credit crisis has attracted attention to financial derivative instruments, more frequently arises questions about fair value calculations. Over the time, different models had been introduced. All of those models take into account factors affecting prices. Mostly, factors used in calculations on the same type of financial instruments are approximately the same. Therefore question arises, which factor affects price more and which less, with no matter which model would be used for fair value calculations. One of financial derivative instrument types is options. Options are agreements, which give to option buyer rights to buy or sell underlying asset. While the seller or writer of option has obligation to buy or sell underlying asset. This research aims to explore the impact of factors on option fair value calculations and evaluate most important ones from those, which could be chosen by option buyer or seller. To reach the aim of research following tasks are developed: 1) review of fair value calculation models; 2) compare results of usage of different models and changes in affecting factors; 3) highlight differences between option price affecting factors, models used in calculations and results provided. Research includes literature review and analysis of option pricing results. Option price calculations are based on historical option prices, using black-Scholes and Binomial option pricing models.
\end{abstract}

KEYWORDS: options, fair value models, strike price, exercise date.

\section{JEL CODES: G1 General Financial Markets}

\section{Introduction}

Questions about most appropriate valuation models, to ensure impossibility of customer delusion, arises time by time. As all painful questions, they come to light after crisis situations. This has happened also with fair value calculations as the current global situation in financial markets has become tenser after subprime credit crisis.

The aim of this article is to show importance of both market factors and models used in option fair value calculations.

The object of the research is option fair value models.

The tasks of the paper are as follows:

- To review theoretical background of fair value calculation models.

- To compare results of model usage in stock option valuation on different factors.

- To highlight differences between option price affecting factors, models used in calculations and results provided.

In order to achieve the tasks of the paper theoretical and empirical research methods are used. For option pricing model research was used analysis of scientific publications and option price calculation of quoted stock options.

1 Ance Martinova - University of Latvia, Faculty of Economics and Management

E-mail: ance.martinova@gmail.com

Tel.: +37126473919 
The structure of the paper is as follows. The first section provides theoretical description of option fair value calculations and factors affecting results. The second section uses models discussed in first section to analyse factor importance differences. At the conclusion, author gives summary of calculation result and factor influences.

\section{Theoretical Background}

Generally, derivative contracts are divided into two subsections: those who cover obligations to sell or buy underlying asset and those who gives right to sell or buy underlying asset. Among first group are derivative instruments as forwards, futures and swaps. As main representative of second division is option agreement. An option is afinancial instrument that gives one party the right, but not the obligation, to buy or sell anunderlying asset from or to another party at a fixed price over a specific period of time (Chance, 2003: 6).

Option contracts have separate types, which are reflected to:

1. Underlying asset, e.g., stock options, commodity options and FX options.

2. Trading market (Exchange traded options and over the counter options).

3. Exercise time, e.g., American or European options. American type options can be exercised at any time upon maturity date, therefore European type options can be exercised only at expiration of option contract.

Therefore all option types have common descriptive values:

- Effective date - date, when option contract starts.

- Maturity date - date, when option contract stops working.

- Strike price - price at which underlying asset could be sold or bought.

- Underlying asset - asset on which base price is calculated - it's current price and the volatility.

- Risk-free interest rate.

Despite specifics of each of option types, all of them have market value by which option contract counterparties can determine their advantage or disadvantage of taking step into derivative contract. For valuing option contracts fair value should be determined.

Option pricing includes usage of price volatility parameter. The volatility parameter can be estimated either from historical data (historical volatility) or implied from the European options (implied volatility) (Muzzioli, Reynaerts, 2008: 141). For more precise market price determination implied volatility should be used, as it implies future value expectations. However, implied volatility calculated from option pricing models did not reflect underlying assets volatility. Implied volatilities vary with strikes and maturities, which are respectively known as the smile effect and the term structure (Deng, Yu, Yang, 2008: 17).

Both factors are known as Markov process. A Markov process is a stochastic process where only the present value of the variable is relevant for predicting the future (Coelen, 2002: 4).

Another problem of obtaining the volatility of the underlying asset from the Black-Scholes formula was noted into Chargoy-Corona and Ibarra-Valdezand research. They concluded that given market option values has become a very important issue in Finance, and hence there have been developed two main lines of research, one quite theoretical, and the other very practical. Both assume the impossibility of obtaining closed form solutions for the implied volatility in stock market are well-known evidences that market prices reflect the present price and information are absorbed at the notice (Chargoy-Corona, Ibarra-Valdezand, 2006: 687).

GianlucaVagnani also noted that using the Black-Scholes option pricing model, if to plot the implied volatility as a function of the exercise price, should be obtained a horizontal straight line. This implies that all options for buying or selling the same underlying asset with the same expiration date, but with different exercise prices, should have the same implied volatility. This is not, however, what occurs in practice in option markets worldwide. The implied volatility presents a strong U-shaped pattern, as the call option goes from deep in-the-money to at-the-money and then to deep out-of-the-money, or as the put option goes from deep out-of-the-money to at-the-money and then to deep in-the-money (Vagnani, 2009: 103). 


\subsection{Black-Scholes Option Pricing Model}

The most popularity gained option pricing model is Black-Scholes model (a.k.a. Black-Scholes-Merton model). It was introduced by Fisher Black, Myron Scholes and Robert Merton in 1970. In nowadays, it is considered to be backbone of option pricing as such.

Black-Scholes model uses following formulas (Hull, 2009: 291):

$$
\begin{aligned}
& c=S_{0} N\left(d_{1}\right)-K e^{-r T} N\left(d_{2}\right) \\
& p=K e^{-r T} N\left(-d_{2}\right)-S_{0} N\left(-d_{1}\right)
\end{aligned}
$$

Where

$$
\begin{aligned}
& d_{1}=\frac{\ln \left(\frac{S_{0}}{K}\right)+\left(r+\frac{\sigma^{2}}{2}\right) T}{\sigma \sqrt{T}} \\
& d_{2}=\frac{\ln \left(\frac{S_{0}}{K}\right)+\left(r-\frac{\sigma^{2}}{2}\right) T}{\sigma \sqrt{T}}=d_{1}-\sigma \sqrt{T}
\end{aligned}
$$

$C=$ European call price;

$P=$ European put price;

$S_{0}=$ Stock price at time zero;

$K=$ Strike price;

$r=$ Continuously compounded risk-free rate;

$\sigma=$ Stock price volatility;

$T=$ Time to maturity of the option.

The Black-Scholes model follows to assumptions called "ideal conditions":

- The short-term interest rate is known an discontent through time.

- The stock price follow Sarandon walk on continuous time with a Varian cerate proportional to the square of the stock price. Thus the distribution of possible stock price sat the end of any finite interval is lognormal. The Varian cerate of there turn on the stock is constant (Clarkson, 1995: 1128).

Basically, model was used for determination of option's price. However, Black-Scholes model can be used for risk measurement and management purposes. In risk management processes often are used delta measurement. Delta can be used to train risk assets management. One option is selling party sold to avoid risk, must take this risk, selling party. When the strategies of risk control, buy a train of proper share with its assets, and train a hedge. (Zhao, Xue, Wu, 2011: 3793). This risk management side of model usage has become even more popular after financial crisis, which caused even larger attention to it.

\subsection{Binomial Option Pricing Model}

Binomial option pricing model is one of the simplest methods for valuing options. Binomial option pricing model tree consists of possibilities for price (S) to either go up (uS) or down (dS) (see Figure 1). 


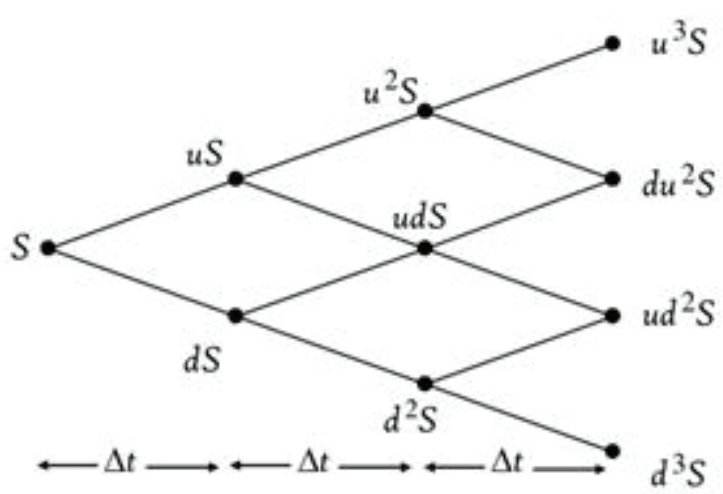

Figure 1. Binomial Tree with Three Steps (Alexander, 2008: 149)

It was introduced by John C. Cox, Stephen A. Ross and Mark Rubinstein, in 1979. In binomial option pricing model it is assumed that the stock price follows a multiplicative binomial process over discrete periods, the interest rate is constant, individuals may borrow or lend as much as they wish at this rate and that there are no taxes, transaction costs, or margin requirements (Cox, Ross and Rubinstein, 1979: 232).

N. Schumacher in his research concluded that most important type of model misspecification is the assumption of constant interest rates. He proposed that a significant improvement could be made if it were assumed that investors are indeed risk-neutral given the assumed constant interest rate environment (Shcumacher, 1999: 20).

Binomial option pricing models basically was introduced for European option pricing. However, with increasing demand for American style options, there have been made parameterization of the binomial tree to provide possibility to price both, European and American style options.

\section{Main Results of Research}

In financial markets, there is possibility to choose strike price and expiration time. Both of those factors affect market price calculations, no matter what type of pricing model is used.

Research of this paper was based on that how differences of optional factors impact option price calculated and those provided in exchange market. Although results differ from one to another option, there have been common trend observed. Calculations based on changes of call option strike prices, give results that both models are close to market price, when strike price is above underlying asset's price, but quite far for lower strike prices (see example in Figure 2). However, the greatest differences are produced by Binomial option pricing model.

Absolutely different situation, when calculations are based on put options. Mostly, there are no material differences for both, Black-Scholes and Binomial option pricing models (see example in Figure 3). 


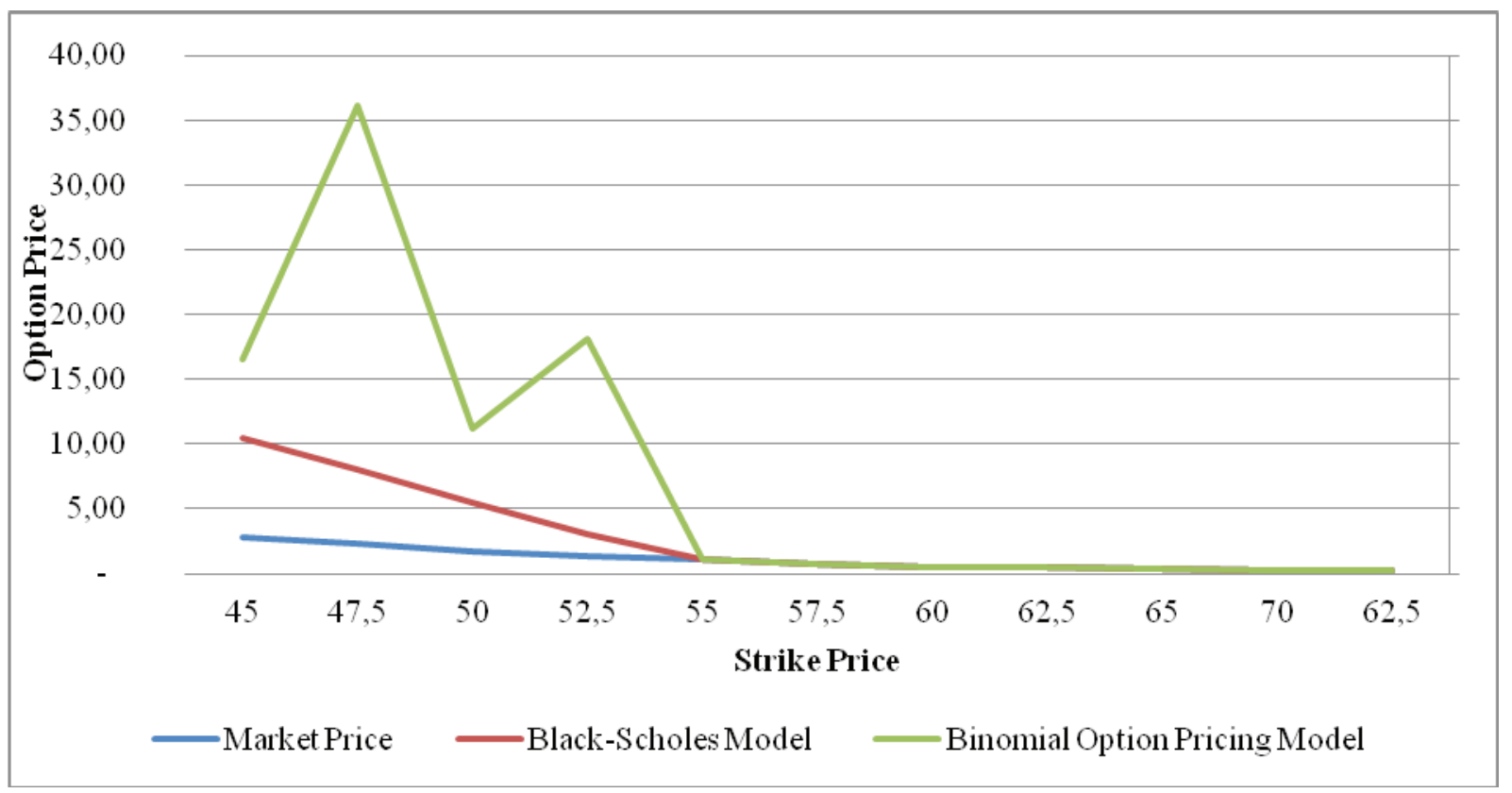

Figure 2. DECK Call Option Price Differences Impacted on Models and Strike Prices Used

Source: Figure made by the author(Company symbol: DECK, Stock price: 55,47 USD, Prices on 11.04.2013)

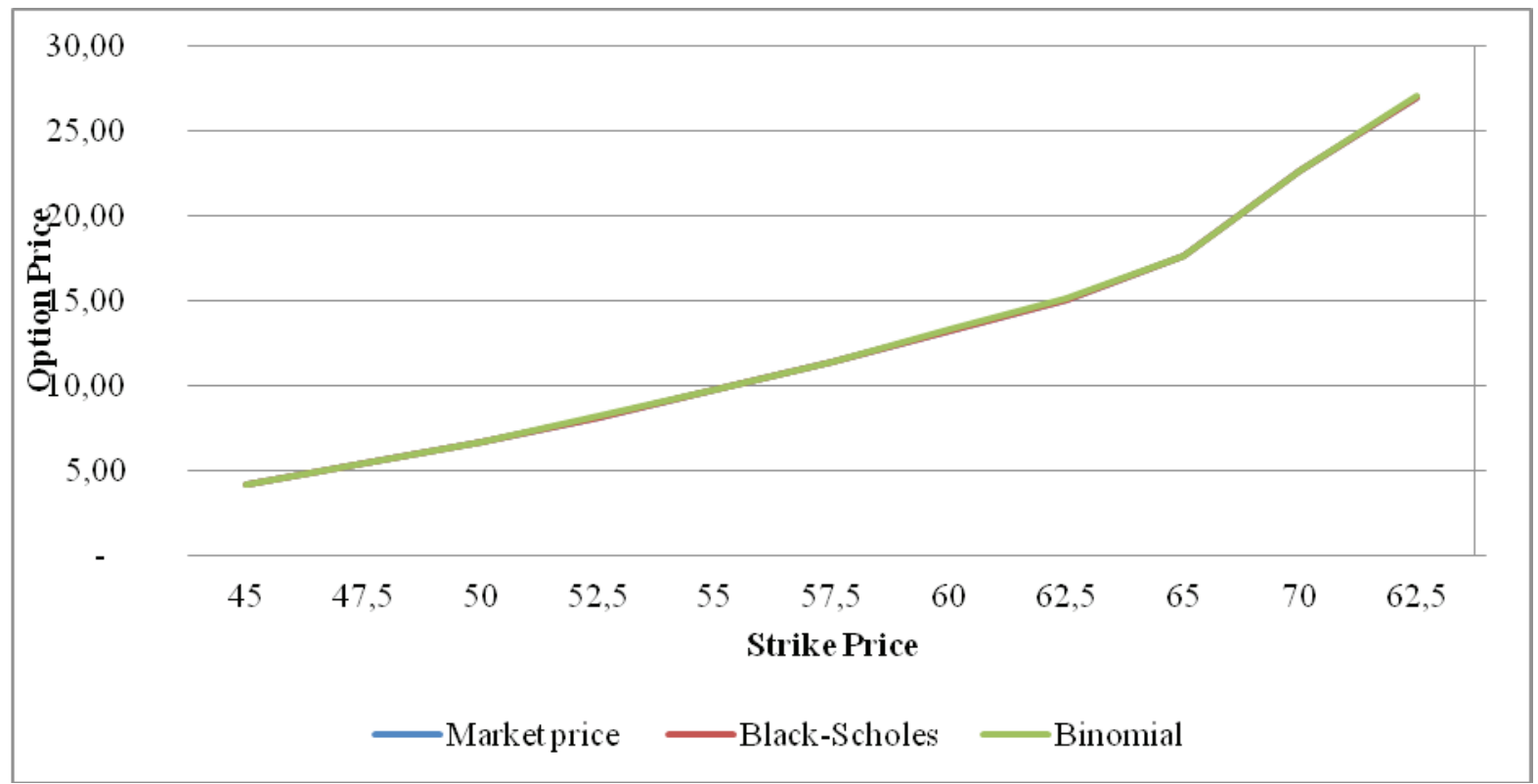

Figure 3. DECK Put Option Price Differences Impacted on Models and Strike Prices Used

Source: Figure made by the author (Company symbol: DECK, Stock price: 55,47 USD, Prices on 11.04.2013)

As previously discussed in the paper, option prices are affected also by expiration date - on the fact how long is option's residual time. There have been seen more uncertainties than for strike price changes, there is larger differences in results calculated. When strike price is above underlying stock price, results from both models are almost the same as market price available, with no matter what is option's residual time (see example in Figure 4). However, for shorter term call options price calculated by Black-Scholes option pricing model is same as provided by exchange, but Binomial model gives price equal to zero. 


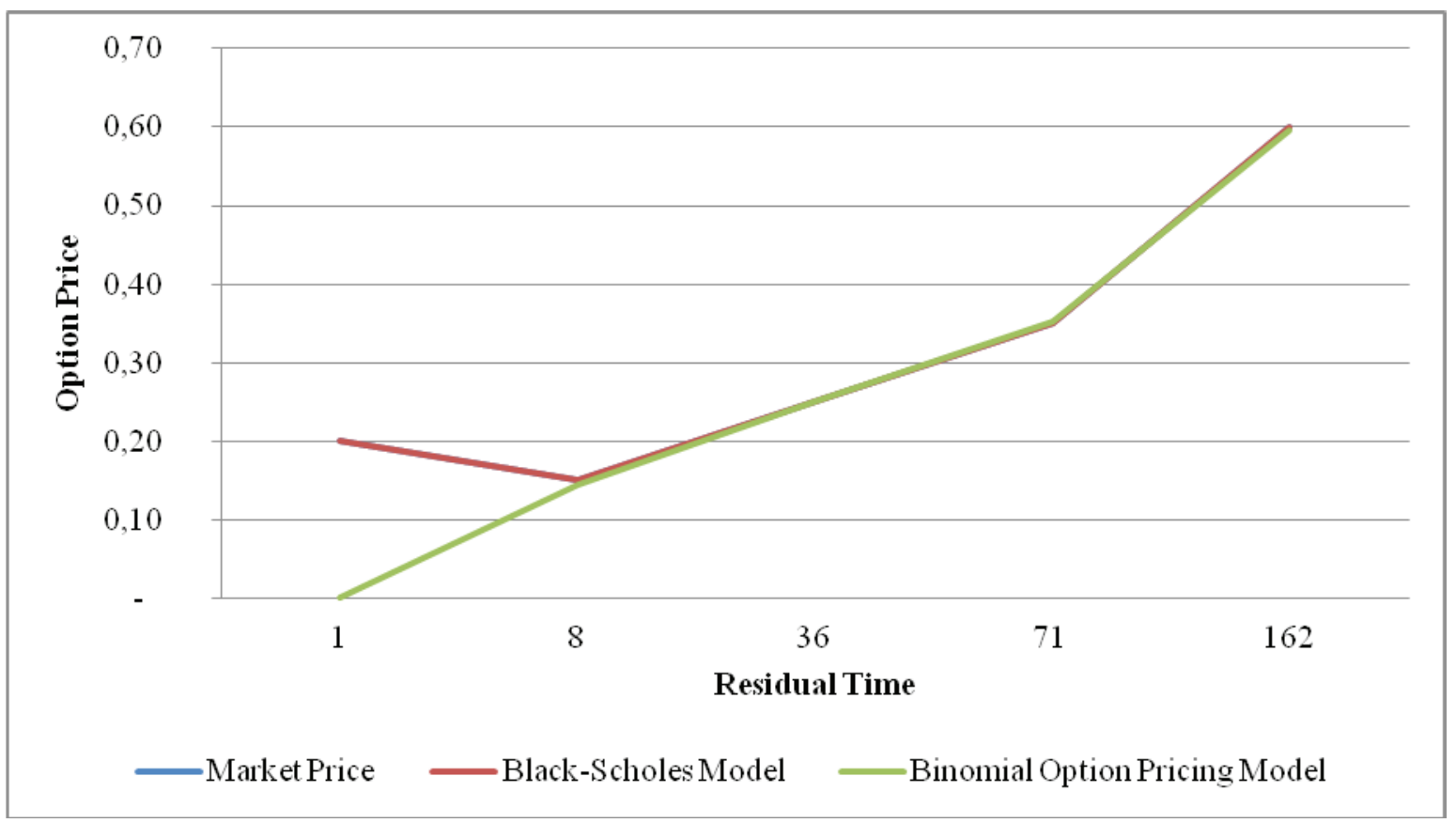

Figure 4. DECK Call Option Price Differences Impacted on Models and residual Time Used

Source: Figure made by the author (Company symbol: DECK, Stock price: 55.47 USD, Strike price: 70 USD Prices on 11.04.2013)

Quite similar situation for options with higher strike price, then underlying stock price, is for put options (see example in Figure 5). The difference in shorter term options are not so large as for call options, but anyway there have been seen tendencies for Black-Scholes model to provide more closer to real market prices.

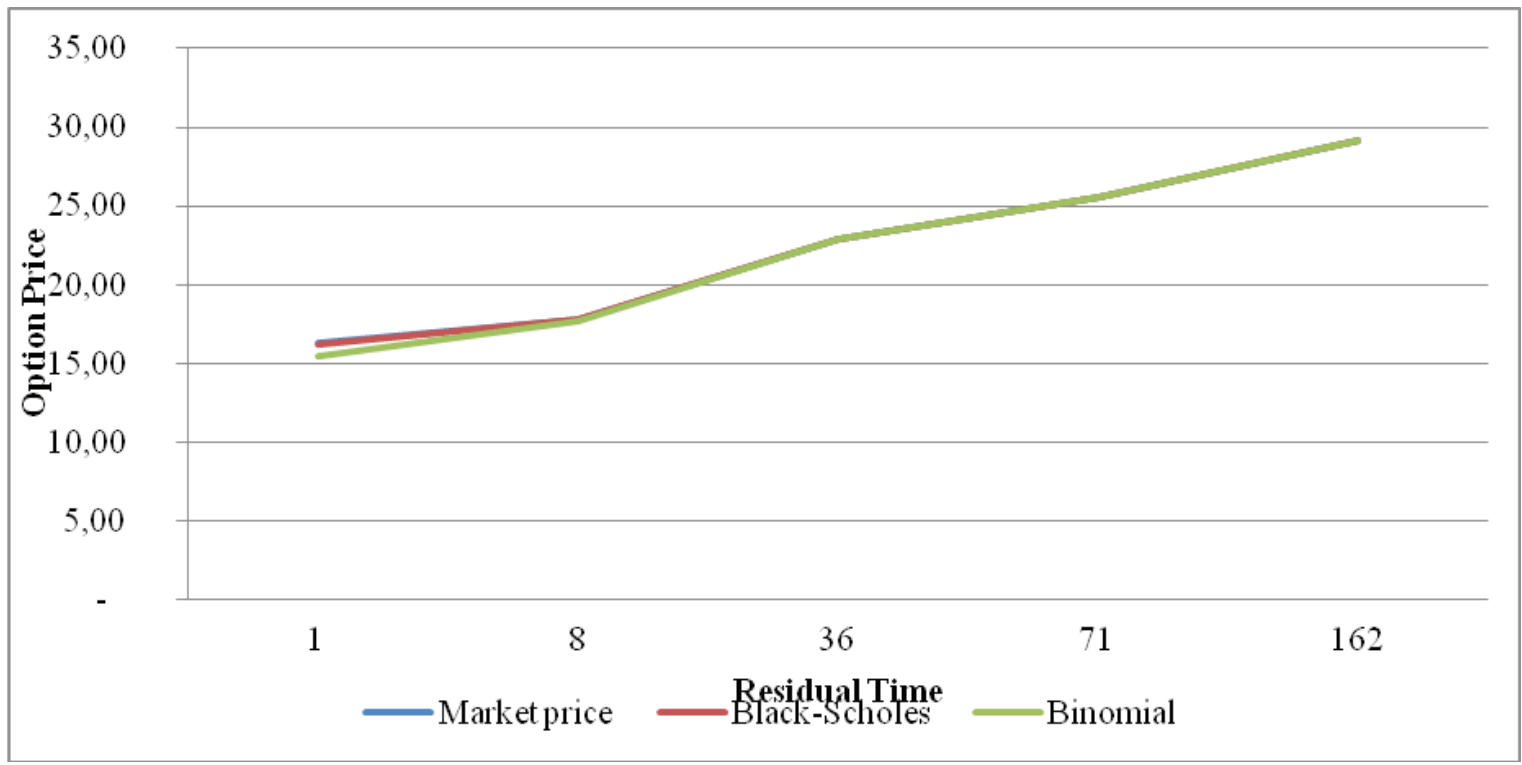

Figure 5. DECK Put Option Price Differences Impacted on Models and Residual Time Used

Source: Figure made by the author (Company symbol: DECK, Stock price: 55.47 USD, Strike price: 70 USD Prices on 11.04.2013)

For options with strike price below underlying stock price, there have been observed huge differences between option pricing models used and residual time left (see example in Figure 6). The most unrealistic 
results were calculated using Binomial option pricing model. Although Black-Scholes model gives closer results, they are more than twice larger than prices provided by exchange.

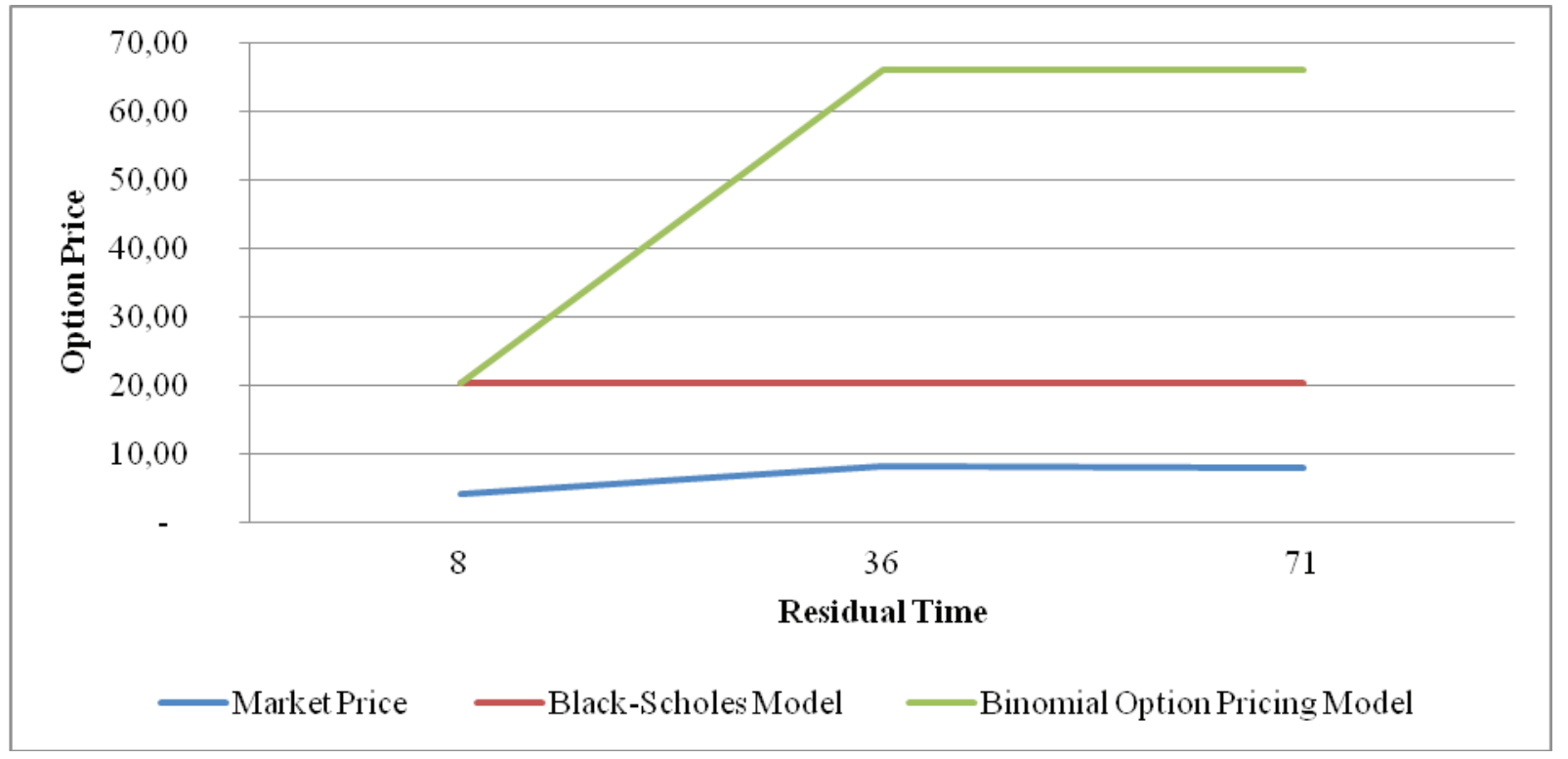

Figure 6. DECK Call Option Price Differences Impacted on Models and Residual Used

Source: Figure made by the author (Company symbol: DECK, Stock price: 55.47 USD,

Strike price: 35 USD Prices on 11.04.2013)

For put options with lower strike price than underlying stock's price, results provided by using BlackScholes model are one by one with market rates (see example in Figure 7). However, Binomial model tends to provide lower prices for almost all length options.

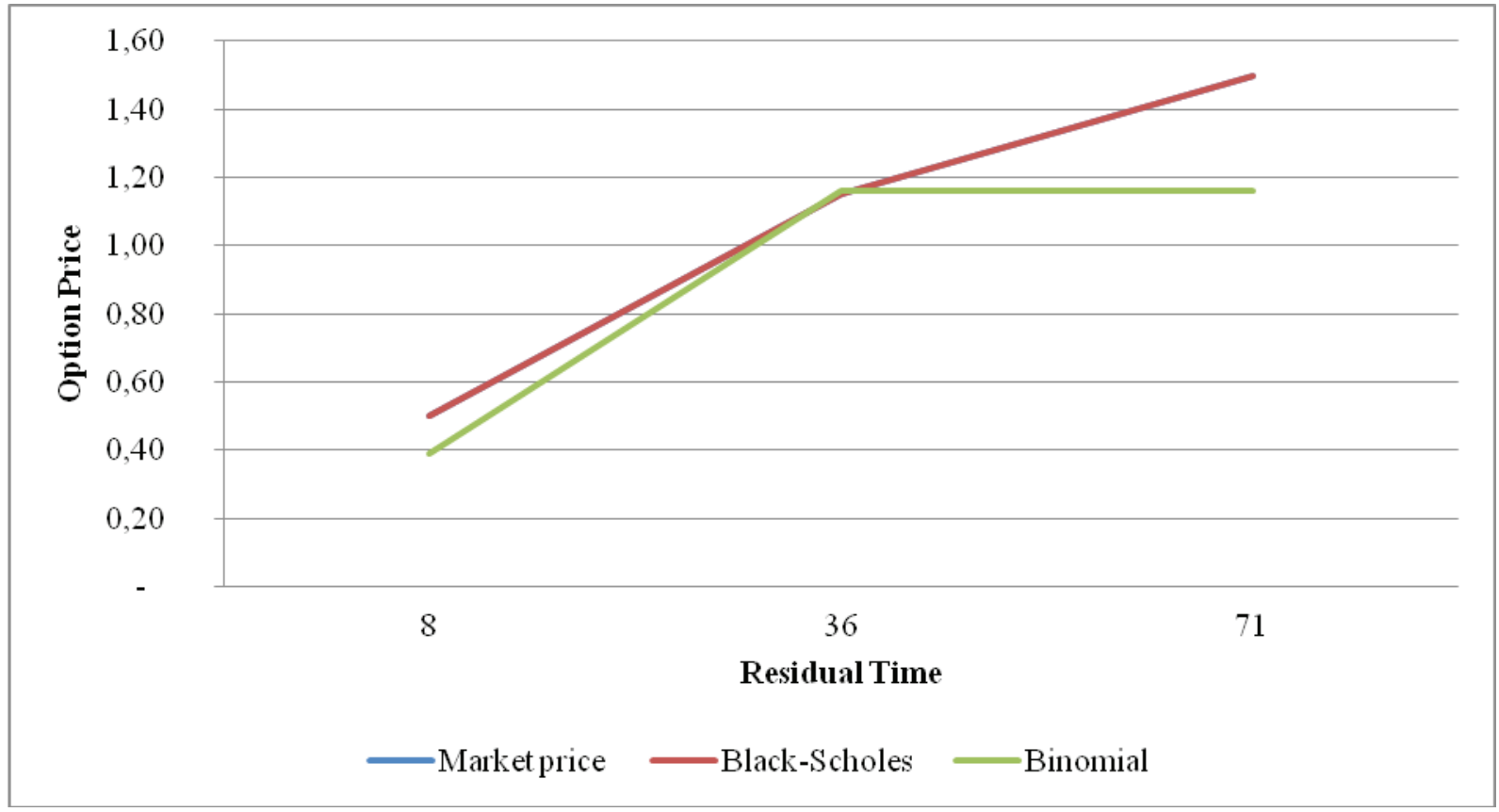

Figure 7. DECK Put Option Price Differences Impacted on Models and Residual Time Used

Source: Figure made by the author (Company symbol: DECK, Stock price: 55.47 USD,

Strike price: 35 USD Prices on 11.04.2013) 
Above provided examples of option pricing results, gives insight that most probably in some market conditions other factors gives larger impact. Uncertainties in results could be related with market tendencies to include fundamental information into value creation of financial instruments, known as relative value.

\section{Conclusions}

If we assume perfect market conditions and ignore possibility of model errors, such as fat-tails, then research on option pricing with different factors gives conclusion that in most of cases, Black-Scholes model are more precise. It gives closer results to real market prices provided by exchanges, than Binomial pricing model. Therefore, it could be thought that Black-Scholes model could be used not only for assuming real value of option already owned, but also for selecting appropriate option trading strategy.

For stock call options with the same exercise date and different strike prices, both - Black-Scholes and Binomial option pricing models gives approximately the same results, when strike price is above stock spot price. Quite similar are also results for call options with same strike price and different exercise dates, where results from both models are also similar, when strike price exceeds spot price.

For put options, most similar results from both models and very close to market prices are provided for options with the same exercise time and different strike prices and for options with different exercise prices where strike price exceeds spot price.

However, it cannot be excluded that errors on models exist. For more precise option valuation, there should be made assumptions and evaluation on every factor used in pricing models. The most precise calculations would come from amalgamation of different models, such as Value at Risk approaches.

\section{References}

Alexander, C. (2008). Market Risk Analysis. Vol. III: Pricing, Hedging and Trading Financial Instruments. UK: John Wiley \& Sons, Ltd, $390 \mathrm{p}$.

Chance, D. M. CFA (2003). Analysis of Derivatives for the CFA ${ }^{\circledR}$ Program. USA: Association for Investment Management and Research $^{\circledR}, 657 \mathrm{p}$.

Chargoy-Corona, J., Ibarra-Valdez, C. (2006). A note on Black-Scholes implied volatility. Physica A 370, p. $681-688$.

Clarkson, R. S. (1995). Some Observations on the Black-Scholes Option Pricing Formula. Scotland: $5^{\text {th }}$ AFIR International Colloquium, p. 1125-1136.

Coelen, N. (2002). Black-Scholes Option Pricing Model. USA: Trinity University, 19 p.

Cox, J. C., Ross, S. A., Rubinstein, M. (1979). Option Pricing: A Simplified Approach. Journal of Financial Economics, Vol. 7, p. 229-263.

Deng, Z. C., Yu, J. N., Yang, L. (2008). An Inverse Problem of Determining the Implied Volatility in Option Pricing. Journal of Mathematical Analysis and Applications, Vol. 340, Issue 1, p. 16-31. USA.

Hull, J. C. (2009). Options, Futures, and Other Derivatives. USA: Pearson Prentice Hall, 814 p.

Mazzioli, S., Reynaerts, H. (2008). American Option Pricing with Imprecise Risk-Neutral Probabilities. International Journal of Approximate Reasoning, Vol. 49, p. 140-147.

Schumacher, N. (1999). Binomial Option Pricing with Nonidentically Distributed Returns and its Implications. Mathematical and Computer Modelling, Vol. 29, p. 121-143.

Vagnani, G. (2009). The Black-Scholes model as a determinant of the implied volatility smile: A simulation study. Journal of Economic Behavior \& Organization, Vol. 72, p. 103-118.

Zhao, D. J., Xue, L., Wu, M. H. (2011). The Modification of Black-Scholes Option Pricing Model Applied in Business Evaluation for High-tech Enterprise, Vol. 15, p. 3791-3795. USA: Procedia Engineering. 


\section{OPCIONŲ VERTÉS SKAIČIAVIMO KOMPONENTAI}

Ance Martinova

Latvijos universitetas (Latvija)

\section{Santrauka}

Opcionai yra viena populiariausių finansinių išvestinių priemonių. Didejjant jos populiarumui, kyla poreikis tiksliai nustatyti vertės opcionus. Black-Scholes ir binominis opcionų kainų nustatymo modeliai yra populiariausi opcionų vertės nustatymo modeliai, kuriuos taiko finansų specialistai. Abu pagrissti panašiomis prielaidomis, tačiau turi ir šiokių tokių skirtumų, todèl taikant juos rinkos sąlygomis galimi skirtingi rezultatai. Skaičiavimo komponentai gali būti suskirstyti ị keletą grupių: tie, kuriems įtakos neturi opcionų naudotojai - pirkejjai ir pardavejjai, ir tie, kurie priklauso nuo pirkejjų ar pardavejjų sprendimo. Šiame straipsnyje nagrinèjama antroji grupé, ypatingas dėmesys kreipiamas į vykdymo kainą ir datos įtaką opcionų vertei. Tyrimo tikslas - palyginti opcionų vertès nustatymo modelius įvairiomis rinkos sąlygomis, nustatyti jiems įtaką darančius veiksnius. Tyrimo rezultatai patvirtina, kad Black-Scholes modelis duoda tikslesnius rezultatus nei binominis opcionų vertẻs nustatymo modelis, tačiau tik idealios rinkos sąlygomis. Tyrime taikytas mokslinės literatūros analizės metodas ir opcionų vertès skaičiavimai.

PAGRINDINIAI ŽODŽIAI: opcionai, vertès skaičiavimo modeliai, vykdymo kaina, vykdymo data.

JEL KLASIFIKACIJA: G1 